\title{
Correction: Guideline levels for PFOA and PFOS in drinking water: the role of scientific uncertainty, risk assessment decisions, and social factors
}

\author{
Alissa Cordner ${ }^{1} \cdot$ Vanessa Y. De La Rosa $^{2,3} \cdot$ Laurel A. Schaider ${ }^{2} \cdot$ Ruthann A. Rudel $^{2} \cdot$ Lauren Richter $^{3} \cdot$ Phil Brown $^{3,4}$
}

Published online: 29 March 2019

(c) The Author(s) 2019. This article is published with open access

\section{Correction to: Journal of Exposure Science \& Environ- mental Epidemiology \\ https://doi.org/10.1038/s41370-018-0099-9 \\ published online: 8 January 2019}

This paper was originally published under a standard licence. This has now been amended to a CC BY licence in the PDF and HTML.
Open Access This article is licensed under a Creative Commons Attribution 4.0 International License, which permits use, sharing, adaptation, distribution and reproduction in any medium or format, as long as you give appropriate credit to the original author(s) and the source, provide a link to the Creative Commons license, and indicate if changes were made. The images or other third party material in this article are included in the article's Creative Commons license, unless indicated otherwise in a credit line to the material. If material is not included in the article's Creative Commons license and your intended use is not permitted by statutory regulation or exceeds the permitted use, you will need to obtain permission directly from the copyright holder. To view a copy of this license, visit http://creativecommons. org/licenses/by/4.0/.
Alissa Cordner

cordneaa@whitman.edu

1 Department of Sociology, Whitman College, Walla Walla, WA, USA

2 Silent Spring Institute, Newton, MA, USA

3 Department of Sociology and Anthropology, Northeastern University, Boston, MA, USA

4 Department of Health Sciences, Northeastern University, Boston, MA, USA 